NBER WORKING PAPER SERIES

\author{
HONG KONG'S CURRENCY BOARD \\ AND CHANGING MONETARY REGIMES
}

Yum K. Kwan

Francis T. Lui

Working Paper 5723

\author{
NATIONAL BUREAU OF ECONOMIC RESEARCH \\ 1050 Massachusetts Avenue \\ Cambridge, MA 02138 \\ August 1996
}

This paper was presented at NBER's East Asian Seminar on Economics, and the NBER conference "Universities Research Conference on the Determination of Exchange Rates." This work is part of NBER's project on International Capital Flows which receives support from the Center for International Political Economy. We are grateful to the Center for International Political Economy for the support of this project and to Barry Eichengreen and Zhaoyong Zhang for helpful and constructive comments. Any opinions expressed are those of the authors and not those of the National Bureau of Economic Research.

(C) 1996 by Yum K. Kwan and Francis T. Lui. All rights reserved. Short sections of text, not to exceed two paragraphs, may be quoted without explicit permission provided that full credit, including $\odot$ notice, is given to the source. 


\title{
HONG KONG'S CURRENCY BOARD AND CHANGING MONETARY REGIMES
}

\begin{abstract}
The paper discusses the historical background and institutional details of Hong Kong's currency board. We argue that its experience provides a good opportunity to test the macroeconomic implications of the currency board regime. Using the method of Blanchard and Quah (1989), we show that the parameters of the structural equations and the characteristics of supply and demand shocks have significantly changed since adopting the regime. Variance decomposition and impulse response analyses indicate Hong Kong's currency board is less susceptible to supply shocks, but demand shocks can cause greater short-term volatility under the system. The decent performance of Hong Kong's currency board is due mainly to the stable fiscal policy of its government. Counterfactual exercises also show that three-fourths of the reduction in observed output volatility and twothirds of that in observed inflation volatility are explained by the adoption of the currency board, while the remainder is explained by changes in the external environment. The improvement in stability does not rule out the possibility of monetary collapse, however.
\end{abstract}

Yum K. Kwan

Centre for Economic Development Hong Kong University of Science and Technology Clearwater Bay, Kowloon HONG KONG
Francis T. Lui

Centre for Economic Development Hong Kong University of Science and Technology Clearwater Bay, Kowloon HONG KONG 


\section{Introduction}

Currency board, first introduced in the British colony of Mauritius in 1849, is a rule-based monetary institution that is rather different from a central bank. Although there are variations, a typical currency board has two essential characteristics. First, the board has the obligation to exchange on demand local currency for some major international currency, which is often called the reserve currency, and vice versa, at a fixed exchange rate stipulated in the legislation. Second, local currency is issued based on at least 100 percent reserve of securities denominated mainly in the reserve currency.

Since the nineteenth century, dozens of currency boards had been established in British colonies and other places, often in response to monetary or exchange rate disturbances. ${ }^{1}$ However, when these colonies became independent nations after World War II, most of them decided to replace the currency board with a central bank. Only very few currency boards still survive today. Some people may be inclined to believe that this form of monetary institution has already lost its practical importance. This judgment is premature. Recently, Argentina and Estonia have enacted laws to establish currency boards, which have also been recommended for Russia, Bulgaria and some other nations in Eastern Europe (see Hanke, Jonung, and Schuler (1993)). The currency crisis of Mexico in 1995 has further stimulated people to consider the system seriously. If this renewed interest could be sustained and these countries were to adopt currency boards eventually, then as Schwartz (1993) had commented, "a watershed would have been reached in the annals of political economy."

For more detailed discussion of the history of currency boards, see Schwartz (1993) and Hanke and Schuler (1994). See also Walters and Hanke (1992). 
Do the potential benefits of currency boards outweigh their costs in these countries? Some of the theoretical advantages and disadvantages of currency boards are well known. ${ }^{2}$ For example, convertibility of currency is guaranteed and there is little or no uncertainty about the exchange rate. On the other hand, in times of domestic liquidity crisis, a currency board arrangement cannot act as a lender of last resort. In theory, its reserve currency can only be used to buy local currency or foreign securities. It would be a violation of its basic principle if the reserve were to be used to purchase the assets of a domestic bank suffering from a run. ${ }^{3}$ Moreover, since currency board is a rule-based arrangement, active discretionary monetary policies are precluded. Whether this macroeconomic self-discipline is regarded as an advantage, however, is more controversial.

To assess the viability of adopting currency boards as the monetary institution, we should not satisfy ourselves with theoretical discussions alone. Since they have been in existence for almost one and a half centuries, a more fruitful approach is to analyze rigorously the empirical data generated from actual experience. This literature is generally lacking. In this paper, we shall analyze the macroeconomic implications of a currency board regime using Hong Kong data and methods developed by Blanchard

2 Williamson (1995) provides a useful summary of the advantages and disadvantages of currency boards.

3 The currency board of Hong Kong is an exception to this rule. There is no formal legislation prohibiting the board from using its foreign exchange to purchase domestic assets, although the board has so far refrained from doing so in a significant way. See the balance sheet in Table 7 . One interpretation is that the legislature provides an "escape clause" with which the board can act as a lender of last resort during financial crises. As long as the escape clause is only invoked in truly exceptional and justifiable situations, it will not jeopardize the credibility of the currency board. See Persson and Tabellini (1991) for an illustration and discussion of escape clause models. See also footnote 14 . 
and Quah (1989) and Bayoumi and Eichengreen (1993, 1994). The viability of the regime is also discussed.

In the next section, we shall briefly discuss the historical background of Hong Kong's currency board and argue why its experience provides us with a unique natural experiment to evaluate some aspects of the system. In Section 3, we shall outline the structural vector autoregressive (VAR) model implemented in this paper. Section 4 presents the quantitative results and their interpretations. Section 5 summarizes some general properties and implications about currency boards that we have learned from the Hong Kong experience.

\section{Historical Background of Hong Kong's Currency Board}

The currency system of Hong Kong, following that of China, was based on the silver standard in the nineteenth and early part of the twentieth centuries. ${ }^{4}$ In 1934 , the United States decided to buy silver at a very high fixed rate and that led to large outflow of silver from Hong Kong and China. As a result, both governments abandoned the silver standard. In December 1935, Hong Kong enacted the Currency Ordinance, which was later renamed as the Exchange Fund Ordinance, and purchased all privately held silver coins. At the same time, the note-issuing banks, which were private enterprises, had to deposit their silver reserves with the newly created Exchange Fund and received Certificates of Indebtedness (CIs) in return. The Exchange Fund sold the silver in the London market for sterling. From then on, if an authorized bank wanted to issue more notes, it was obligated to purchase more CIs

\footnotetext{
4 For more details on the historical development of the monetary regime in Hong Kong, see Greenwood (1995), Nugee (1995), and Schwartz (1993).
} 
from the Exchange Fund with sterling at a fixed rate of sixteen HK dollar to one pound. The Exchange Fund would also buy the CIs from the banks if the latter decided to decrease the money supply. Thus, the monetary system had all the features of a currency board, with the exception that legal tenders were issued by authorized private banks rather than directly by the board.

The peg to the sterling lasted for more than three decades, despite four years of interruption during World War II. In 1967, because of devaluation of the sterling, the sixteen HK dollar peg could no longer be sustained. In July 1972 further pressure from the devaluation of the sterling forced the eventual abolition of the link between the sterling and HK dollar. The latter was pegged to the US dollar at a rate within an intervention band. This also did not last long. Again devaluation of the US dollar and an inflow of capital to Hong Kong led to the decision of free-floating the HK dollar against the US dollar. The currency board system was no longer operating.

Under the free-floating. system from 1974 to 1983 , authorized banks still had to purchase CIs, which at this time were denominated in HK dollar, from the Exchange Fund if they wanted to issue more notes. The Fund maintained an account with these banks. The payment for the CIs was simply a transfer of credit from the banks to the account of the Exchange Fund. Starting from May 1979, the note-issuing banks were required to maintain 100-percent liquid-asset cover against the Fund's short-term deposits. This cover did not imply that the Exchange Fund could effectively limit the creation of money because the banks could borrow foreign currency to obtain the liquid assets. Money growth in this period was higher and more volatile than before. In 1978, the government also decided to transfer the accumulated HK dollar fiscal surplus 
to the Exchange Fund, which has since then become the government's de facto savings account.

During the initial phase of the free-floating period, the HK dollar was very strong. However, from 1977 onwards, it was subject to considerable downward pressure. Trade deficit was growing. Money supply, M2, increased at the rate of almost 25 percent a year, mainly because of even faster growth in bank credit. The start of the Sino-British negotiations over the future of Hong Kong in 1982 led to a series of financial crises: stock market crash, real estate price collapse, runs of small banks, and rapid depreciation of the $\mathrm{HK}$ dollar. On October 17, 1983, the government decided to abolish interest withholding tax on HK dollar deposits and more importantly, to go back to the currency board system again. The exchange rate was fixed at US $\$ 1=$ HK\$ 7.8. Banks issuing notes had to purchase CIs with US dollar at this rate from the Exchange Fund. The reserves accumulated were invested mainly in interest-bearing U.S. government securities. Table 1 summarizes the historical evolution of Hong Kong's monetary institutions.

Several new changes to the currency board system of Hong Kong, or now popularly known as the "linked exchange rate system," were introduced. In 1988, the Exchange Fund established the new "Accounting Arrangements" which in effect empowered it to conduct open market operations. Legislative changes also allowed the government to have more flexibility in manipulating the interest rates. Since March 1990, the Fund was permitted to issue several kinds of "Exchange Fund Bills," which were similar to short-term Treasury bills. In 1992, a sort of discount window was opened to provide liquidity to banks. The Hong Kong Monetary Authority (HKMA) 
was established in December 1992 to take over the power of the Exchange Fund Office and the Commissioner of Banking. The HKMA has since been active in adjusting interbank liquidity in response to changes in demand conditions.

Several remarks should be made here. First, the monetary institution in Hong Kong has not been a static system. In less than half a century, it has evolved from the silver standard to a currency board with sterling being the reserve currency, and then to a free-floating regime, and finally back to the currency board with a US dollar link. More recently, as Schwartz (1993) has observed, there has been some "dilution" of the features that distinguish a currency board. Given historical hindsight, one can hardly believe that the present system will last forever, despite the persistent assurance by the Hong Kong Government that the linked exchange rate is there to stay permanently. This view is supported by the observation that historically all fixed exchange rate regimes could not be sustained for very long periods. ${ }^{5}$ This motivates us to simulate in Section 4.4 the conditions under which the Hong Kong currency board may collapse.

Second, from 1974 to now, Hong Kong has used two polar cases of monetary systems, namely, free-floating (1974-83) and currency board (1983-now). There have been no other economic institutional changes of comparable order of magnitude. The government still adopts the "active non-interventionism" policy formulated more than two decades ago. It has been persistently keeping the size of the government small and leaving small budgetary surpluses in most fiscal years. It has also refrained from using fiscal policy as a fine-tuning tool. The legal system has remained intact and Hong Kong's economic freedom has always been rated at the highest level by international

5 Eichengreen (1994) casts doubt on the future of any pegged exchange rate regime in the 21 st century. He predicts that only the two extremes of flexible exchange rate and monetary unification will survive. 
agencies. These similarities in the two periods provide us with a relatively homogeneous setting to conduct a natural controlled experiment to compare the implications of the two systems.

Third, while structural homogeneity is needed for the controlled experiment on the one hand, sufficiently rich data variation is necessary for statistical purpose on the other. If the economic conditions of the two periods had remained perfectly stable, then the data would hardly contain enough information for inferring the macroeconomic performance of the two systems. We need to observe how the two regimes respond to external shocks. Indeed Hong Kong as a small open economy is extremely sensitive to external shocks which may overshadow the "treatment effect" of a currency board system. Fortunately, by adopting the approach in Blanchard and Quah (1989), it is possible to isolate the supply and demand shocks during the two periods. Counter-factual simulations can be performed to identify the effects of the change in monetary regime.

Fourth, Hong Kong has gone through a number of major economic shocks from 1974 to now. This period covers the time span of several business cycles. There have also been big swings in real estate and stock markets. The quarterly data available are reasonably rich in variations which allow us to make meaningful inferences.

Lastly, the economic health and significant financial strength of Hong Kong provide an almost ideal situation to test the vulnerability of a currency board system when it is confronted with a crisis. At the end of 1995, foreign currency assets in the Exchange Fund amounted to US $\$ 57.2$ billion, which was the world's seventh largest. The ratio of foreign currency assets in the Exchange Fund to currency in circulation was bigger than five. The value of the government's accumulated fiscal reserve was 
also substantial. In fact, it was contributing to one-third of the Exchange Fund (see Hong Kong Monetary Authority (1996)). If simulations show that Hong Kong's currency board has to face a crisis when it is subject to shocks of specified magnitude, then it is hard to imagine that the currency board in a country with poorer economic health can survive under the same scenario.

\section{Empirical Model}

In this Section, we discuss a framework that will be used to compare the macroeconomic performance of the flexible and linked exchange rate regimes when they are subject to exogenous shocks. To properly take into account the heterogeneity induced by these shocks, we adopt Blanchard and Quah's (1989) approach to identify them explicitly.

Our empirical framework is the structural vector autoregressive (VAR) model initiated by Blanchard and Watson (1986), Sims (1986), and Bernanke (1986). Following Blanchard and Quah (1989) and Bayoumi and Eichengreen (1993, 1994), we formulate a bivariate model in output growth and inflation rate to identify two series of structural shocks: (1) those whose effects on output level are only transitory, and (2) those that have permanent effects on the output level. Shocks of the first type are interpreted as demand shocks originated from innovations in the components of aggregate demand, while the second type are supply shocks originated from innovations in productivity and other factors that affect aggregate supply. This distinction is crucial for solving the identification problem discussed below. We now briefly describe the model and refer the reader to the above references and the surveys in Giannini (1992) and Watson (1994) for details. 
Let $X_{t}=\left(\Delta y_{t}, \Delta p_{t}\right)^{\prime}$, where $y_{\mathrm{t}}$ and $p_{\mathrm{t}}$ denote the logarithm of output and price level, respectively. $X_{\mathrm{t}}$ is assumed to be covariance stationary and have a moving average representation of the form

$$
X_{t}-\mu=B_{0} e_{\imath}+B_{1} e_{t-1}+B_{2} e_{t-2}+\ldots \equiv B(L) e_{\imath}
$$

where $e_{\mathrm{t}}=\left(e_{\mathrm{dt}}, e_{\mathrm{st}}\right)^{\prime}$ is a bivariate series of serially uncorrelated shocks with zero mean and covariance matrix $\Omega, B(L)=B_{0}+B_{1} L+B_{2} L^{2}+\ldots$ is a short-hand notation for the matrix polynomial in backshift operator $L$, and $\mu$ is the mean of $X_{t}$. (1) is taken to be structural in that $e_{\mathrm{dt}}$ and $e_{\mathrm{st}}$ have a behavioral interpretation of being the demand shock and supply shock, respectively. The coefficient matrices in $B(L)$ capture the propagation mechanism of the dynamic system. In particular, the (i, j) element of $B_{\mathrm{k}}$ is the $\mathrm{k}$ th step impulse response of the $\mathrm{i}$ th endogenous variables with respect to a one unit increase in the $\mathrm{j}$ th shock.

Equation (1) is not directly estimated. We proceed in the following steps. First, we estimate a VAR in $X_{\mathrm{t}}$ :

$$
A(L)\left(X_{t}-\mu\right)=u_{t}
$$

where $\left\{u_{\imath}\right\}$ is a bivariate series of serially uncorrelated errors with zero mean and covariance matrix $\Sigma$, and $A(L)$ is a matrix polynomial in $L$. Second, we invert the estimated autoregressive polynomial in (2) to obtain the Wold moving average representation, which is the reduced form to (1).

$$
X_{t}-\mu=u_{t}+C_{1} u_{t-1}+C_{2} u_{t-2}+\ldots \equiv C(L) u_{t}
$$

Again, $C(L)=I+C_{1} L+C_{2} L^{2}+\ldots$ is short-hand for the matrix polynomial as stated. In our implementation the reduced form VAR is estimated with six lags and the Wold representation in (3) is expanded up to 200 lags which is more than adequate. Given estimates of the reduced form parameters, $C(L)$ and $\Sigma$, and the reduced form residuals 
$u_{t}$, is it possible to recover the structural parameters, $B(L)$ and $\Omega$, and the structural residuals $e_{\imath}$ ? This is a classical identification problem in simultaneous equation models and the answer is yes provided that enough a priori restrictions have been placed on the structural parameters. Comparing (1) and (3) it can be checked that the structural and reduced form are related by the following relationships:

$$
\begin{aligned}
& B_{0} e_{t}=u_{t} \quad \forall t . \\
& B_{j}=C_{j} B_{0}, \quad j=0,1,2, \ldots \\
& B_{0} \Omega B_{0}{ }^{\prime}=\Sigma .
\end{aligned}
$$

Equations (4) and (5) imply that the structural form in (1) can be recovered from the reduced form in (3) once $B_{0}$ is determined. Thus, the identification problem boils down to imposing sufficiently many restrictions so that $B_{0}$ can be solved from (6).

In our bivariate system, there are seven structural parameters in $B_{0}$ and $\Omega$, but only three reduced form parameters in $\Sigma$; we thus need four restrictions to just-identify the structural model. The first three restrictions come from assuming $\Omega$ to be the identity matrix. The zero covariance restriction dictates that the two structural shocks are uncorrelated, implying that any cross-equation interaction of the two shocks on the dependent variables are captured by the lag structure in $B(L)$. The two unit-variance restrictions imply that $B_{0}$ is identified up to multiple of the two standard deviations. Thus $B_{\mathrm{j}}$ has the interpretation of being the $\mathrm{j}$ th step impulse response with respect to a one-standard-deviation innovation in the structural shocks. The last restriction comes from Blanchard and Quah's (1989) idea of restricting long-run multiplier. Since demand shocks are assumed to have no permanent effects on output level, this translates into the restriction that the long-run multiplier (i.e. the sum of impulse responses) of demand shocks on output growth must be zero, i.e. 


$$
B_{11}(1) \equiv B_{11,0}+B_{11,1}+B_{11,2}+\ldots=0
$$

where $B_{1 \mathrm{I}}(1)$ and $B_{11, \mathrm{j}}$ are the upper left-hand corner of $B(I)$ and $B_{\mathrm{j}}$ respectively.

To see how (7) can be translated into a restriction on $B_{0}$, let $J$ be the lower triangular Cholesky factor of $\Sigma$ and notice that (6) can be written as (after assuming $\Omega$ $=\mathrm{I})$

$$
B_{0} B_{0}{ }^{\prime}=\Sigma=J J^{\prime}
$$

Thus $\mathrm{B}_{0}$ can be determined from $J$ up to an orthogonal transformation $S$, i.e.

$$
B_{0}=J S, \quad S S^{\prime}=1 .
$$

Orthogonality implies that S (up to one column sign change) must be of the form

$$
S=\left[\begin{array}{cc}
a & \sqrt{1-a^{2}} \\
\sqrt{1-a^{2}} & -a
\end{array}\right]
$$

(5) and (9) imply

$$
B(1)=C(1) B_{0}=H S, \quad H=C(1) J
$$

(7) then implies a restriction

$$
H_{11} a+H_{12} \sqrt{1-a^{2}}=0
$$

which determines a and hence $S$. Once $S$ is found, $B_{0}$ can be determined by (9). Given $B_{0}$, the structural parameters and the structural shocks can then be recovered from the reduced form via (4) and (5).

The output and price data are quarterly Hong Kong real per capita GDP (in 1990 price) and the corresponding GDP deflator from 1975:1 to $1995: 3$, taken from various issues of Estimates of Gross Domestic Product and Hong Kong Monthly Digest of Statistics published by Hong Kong Government. ${ }^{6}$ Both output and price

6 Quarterly population figures are obtained by log-linearly interpolating the annual data. 
series exhibit strong seasonality and they are deseasonalized before use by a spectral method by Sims (1974) and implemented in Doan (1992, section 11.7). The full sample is divided into two halves corresponding to the two exchange rate regimes: the free float period straddles $1975: 1$ to $1983: 3$ and the currency board period covers $1983: 4$ to $1995: 3$.

\section{Results and Interpretations}

In this Section, we present the empirical results and interpret them. In particular, we use these results to compare the macroeconomic performance of the free-floating and currency board regimes from several perspectives.

\subsection{Institutional Effect or Environment Effect?}

Figures $1 \mathrm{a}$ and $1 \mathrm{~b}$ display the data for the full sample period, covering both the free-floating and currency board regimes. It can be seen that both inflation and output growth are somewhat more stable during the currency board years than the freefloating years. More precisely, the standard deviation of output growth rates during the free-floating and currency board years are 2.94 and 2.23 , respectively, and that of the inflation rates are 1.55 and 1.05 , respectively.

What is behind the observed reduction in volatility in both output growth rates and inflation rates? Some believe that this is simply because of a more congenial international environment during the 1980s than the 1970s. On the other hand, advocates of fixed exchange rate and currency board, including the Hong Kong government, sometimes argue that this is due to the inherent superiority of the linked 
exchange rate regime over the free-floating system (e.g., see Sheng (1995)). Granted that both arguments are reasonable and neither can be rejected a priori, it is then necessary to disentangle the "institutional effect" from the "environment effect." In our structural VAR model, the structural parameters, $B_{j}$ 's, play the role of institution and the structural shocks, $u_{t}$, represent the external environment. By estimating two separate structural models for the two exchange rate regimes, we obtain two sets of structural parameters representing the two institutions and two sets of shocks representing two different external environments. We show below that both the parameters and the shocks have changed.

Table 2 reports the summary statistics of the estimations for equation (1) in Section 3 under free-floating and currency board. It can be seen that they are statistically significant at the 0.01 and 0.001 levels, respectively. The estimated parameters for the structural equation (1) are different across the two regimes. This is evident from a likelihood-ratio version of the Chow test, which rejects the null hypotheses of no structural change at the 5 percent level. ${ }^{7}$ The result supports the Lucas Critique. We need to use a different set of structural parameters to capture the institutional effect due to a change in the monetary regime. It is assumed, however, that these parameters are invariant to the exogenous shocks.

$7 \quad$ The likelihood ratio statistic $\mathrm{LR}=-2\left(\ln \mathrm{L}_{0}-\ln \mathrm{L}_{1}-\ln \mathrm{L}_{2}\right)=-2(699.76-291.85-428.66)=41.5$ rejects the null hypothesis of no structural change at the 5 percent level according to a chi-squared distribution with 26 degrees of freedom. $\ln \mathrm{L}_{0}, \ln \mathrm{L}_{1}$, and $\ln \mathrm{L}_{2}$ are the $\log$ likelihood values of the VARs estimated by using the full sample (75:1 - 95:3), the free float period (75:1 - 83:3), and the currency board period (83:4 - 95:3), respectively. 
Figures $2 \mathrm{a}$ and $2 \mathrm{~b}$ present the quarterly demand and supply shocks (1975-95) that are identified by using the econometric framework in Section 3. Table 3 reports the summary statistics of the shocks. By the skewness and kurtosis tests, one can observe that both types of shocks during the free-floating period exhibit substantial nonnormality which can be attributed to a few large negative shocks. The skewness of the shocks can be clearly discemed from their empirical distributions, depicted in Figures 3a and $3 \mathrm{~b} .^{8}$ Shocks during the currency board period, on the contrary, show no strong evidence against normality, as is clear from the skewness and kurtosis tests and their empirical distributions.

This indicates that the two exchange rate regimes are subject to exogenous shocks of different characteristics. Simply comparing the macroeconomic performance in the two periods without properly controlling for the environment effect can be misleading. This forces us to use better methods.

\subsection{Variance Decomposition and Impulse Response Functions}

The relative importance of demand and supply shocks changes dramatically across the two exchange rate regimes. This is demonstrated by the results on variance decomposition of the shocks and the estimated values of the impulse responses.

8 The empirical distribution is obtained by matching the first four sample moments with a GramCharlier expansion. See Johnson and Kotz (1970), p. 15-20. 
Table 4 shows the percentages of variance in output growth rate and inflation that can be explained by the demand shocks in the last $n$ quarters, where $n$ is the corresponding number in the extreme left column. The percentages explained by the supply shocks are given by 100 minus the table entries. Table 5 is similar to Table 4 , but shows the variance in output level and price level explained. As can be readily seen, during the free-floating regime, demand shocks explain little the variations in output growth and level, but a substantial fraction of inflation or price movements. ${ }^{9}$ On the other hand, supply shocks can account for most of the output changes, but little of the price fluctuations. In the currency board regime, the results are different. Demand shocks can explain much of the variations in the output and price series, at least in the short run. The movements explained by the supply shocks are also substantial.

The dynamic impulse responses of output and price with respect to demand shocks are consistent with the variance decomposition results above. In Figures $4 \mathrm{a}$ and $4 \mathrm{~b}$, the impulse responses, or cumulative effects of demand shocks on output and price during the last $n$ quarters are plotted against $n .{ }^{10}$ The response of output is both smaller and shorter in duration under the flexible exchange regime. On the other hand, the response of price level under the currency board regime is smaller than that under free-floating.

9 The values in the second and third columns of Table 5 decline when $n$ becomes larger. This is because the variance of output level explained by the demand shocks must converge to zero in the long run. Readers are reminded that in Section 3, we have built in the identifying restriction that demand shocks have no long-term effects on output level.

10 The magnitude of the demand shock in each period is one standard deviation. 
Figures $5 \mathrm{a}$ and $5 \mathrm{~b}$ depict the impulse responses of output and price to supply shocks, respectively. The effects of supply shocks on price level across the two regimes are negative, a result consistent with simple economics. The impact of supply shocks on price level in the currency board regime appears to be bigger than that under free-floating. Supply shocks, however, has smaller effect on output during the currency board years. These results are also consistent with the patterns in variance decomposition.

What can we draw from the variance decomposition and impulse response exercises? In fact, the results can be interpreted in a convenient way. The aggregate supply curve during the free-floating years is very steep. It has flattened in the subsequent period. The aggregate demand curve, on the other hand, has a relatively flat slope under free-floating. It has steepened in the currency board regime. These changes in the slope explain why the Chow test detects structural shift in the model.

Why has the aggregate supply curve, or more properly, the short-run supply curve, flattened over time? Bayoumi and Eichengreen (1994) has discovered a similar pattern for the industrial countries over the last one hundred years. The explanation does not necessarily lie in the adoption of the currency board. After all, during part of the sample period studied by Bayoumi and Eichengreen, the countries were moving from fixed exchange to free-floating, while in the case of Hong Kong, it was heading in the opposite direction. The flattening of the short-run aggregate supply curve indicates that there are more nominal rigidities. Probably the latter are due to the increases in labor legislation and union influences in Hong Kong since the 1980s. ${ }^{11}$

\footnotetext{
11 A number of laws on labor protection have been introduced since the 1980s. These range from long-service payment, severance compensation, leaves for pregnant female workers and so forth.
} 
The steepening of the aggregate demand curve under currency board can be usefully analyzed by a simple textbook model (Sachs and Larrain, 1993, Chap. 13 and 14). In a fixed exchange rate regime, an increase in the domestic price will hurt export and increase import. The underlying IS curve of the economy will shift to the left. Since a small open economy has to face a given world interest rate, the LM curve will have to adjust endogenously so that it intersects the IS curve at the level equal to the world interest rate. The decline in output due to the increase in price, and hence the slope of the aggregate demand curve, is therefore completely determined by the magnitude of the movement of the IS curve. In the case of free-floating, an increase in price causes the LM curve to move to the left. The changes in the exchange rate and price will then lead to an adjustment of the IS curve so that it intersects the LM curve at an interest rate equal to the prevailing world interest rate. This time the slope of the aggregate demand curve depends on how responsive the LM curve is with respect to an increase in price. In general, the slope of the aggregate demand curve under currency board can be either steeper or flatter than that under free-floating, depending on the relative responsiveness of the IS and LM curves to a change in price level. It appears that the IS curve in Hong Kong is not as sensitive to price change than the LM curve. Thus the aggregate demand curve is steeper under currency board. ${ }^{12}$

We can draw the following conclusions from the results above. The output in Hong Kong under a currency board seems to be less susceptible to supply shocks, which are usually not induced by government short-term policies. However, demand shocks do cause greater short-term volatility in output under the currency board

12 It can be shown by a simple calibrated model that the IS curve in Hong Kong is not as responsive to price changes as the LM curve. 
system. If a government with a currency board is able to discipline itself to pursue a stable and predictable fiscal policy, the volatility of the economy may be lower than that under free-floating. An explanation of why Hong Kong's economy has been less volatile after the adoption of the linked exchange rate is that stable fiscal policy has always been the philosophy of the financial branch of its government.

\subsection{Counter-factual Simulations}

As discussed in Section 4.1, the two periods under consideration are subject to shocks with different properties. One way to compare the performance of the two regimes is to consider the following two cases:

Case 1: What would have happened to the economy if the currency board system were adopted from 1975 to 1983 ?

Case 2: What would have happened to the economy if the free-floating system were adopted from 1983 to 1995 ?

To answer the question in Case 1, we apply the demand and supply shocks of 1975 to 1983 to equation (1) which has been estimated for the currency board regime, and compare the simulated results with the actual time path. To answer the second question, we do the simulations in a similar way, but this time we apply the shocks of 1983 to 1995 to equation (1) for the free floating regime. The approach is based on the assumption that the supply and demand shocks identified in the estimation procedure of Section 3 are invariant to the change in exchange rate regime. This exogeneity assumption makes a lot of sense for Hong Kong. In this small open economy whose external sector is much larger than its GDP, most of the supply and demand shocks are external. The government has been following the same stable fiscal policy throughout 
the two periods under consideration. Moreover, there is no central bank in Hong Kong to determine the money supply, which is largely rule-based in both regimes and automatically adjusts to external shocks. Thus, there is no a priori reason to believe that the supply and demand shocks are regime dependent.

The counter-factual exercise amounts to replacing the structural residual $e_{t}$ in equation (1) by a hypothetical residual $e_{t}^{*}$ and then simulating a new data path $X_{t}^{*}$, given structural parameters $\mu$ and $B(L)$. For example, in Case $1, e_{\mathrm{t}}, \mu$, and $B(L)$ are the residual and structural parameters for the free-floating regime, while $e_{t}^{*}$ is taken to be the residual for the currency board regime. In practice, however, the moving average representation in equation (1) is difficult to work with. We instead perform the simulation by equation (2) with a reduced form residual $u_{t}^{*}$ constructed from $e_{t} *$ via equation (4). It is straightforward to check that our two-step procedure is equivalent to a direct simulation of equation (1).

Summaries of these counter-factual simulations are presented in Table 6. The results show that if the currency board system were adopted in the first period, then the average growth rate would have declined, but inflation would have gone down also. Since the standard deviations are also lower, we can say that both output growth and inflation would have been more stable. The patterns for the second period are similar. The cost of a currency board system is lower output growth. However, there are also benefits. Inflation rate decreases and the economy is less volatile. The tradeoff 
is transparent when the comparison is in terms of levels (rather than growth rates) as depicted in Figures 6a, b, and 7a, b.

The counter-factual simulations disentangle the effects of regime shift and changes in the external environment. As an example, consider the reduction in output growth volatility when the monetary system changes from free-floating to currency board. The standard deviation of output growth rates goes down from 2.94 to 2.33 , a roughly 32 percent reduction in volatility. From simulation case 1 , we see that if the currency board system were adopted to the environment of the 1970s, output volatility would have declined to 2.46 , a 20 percent reduction from 2.94 . This implies that 62.5 percent of the reduction in output volatility that we actually observe from the data is due to the adoption of the currency board, while the remaining 37.5 percent is due to a more tranquil external environment in the 1980s. Similarly, the marginal effect of the currency board on inflation volatility is to reduce it from 1.55 to 1.21 , or about 28 percent reduction. The observed reduction, however, is from 1.55 to 1.05 , or a decline of 48 percent. One can then have the following decomposition. The difference in external environment during the 1970s and 1980s accounts for 42 percent of the reduction in inflation volatility, while the change in the monetary regime explains the remaining 58 percent of the reduction.

\subsection{Currency and Banking Crises}

The Hong Kong government has been vehemently claiming that the Exchange Fund is financially strong and the linked exchange rate will be defended. As can be seen from the balance sheet of the Fund in Table 7, Hong Kong indeed owns one of the largest foreign reserves in the world. Does it mean that the HK\$ 7.8 link is immune 
from a crisis? In theory, a crisis does not occur even when people exchange all the currency for foreign assets because of the 100 percent back-up. However, one should note that in mid-1995, total M3 equals to $\mathrm{HK} \$ 2244$ billion, which is more than five times bigger than the assets in the Fund. 46.2 percent of this M3 is in bank deposits denominated in foreign money. ${ }^{13}$ Suppose people decide to change the portfolio of M3 by exchanging HK dollar deposits for foreign money. If the change is big enough, the banking sector must sell its domestic assets for foreign money to avoid bank runs. It is not clear whether the Fund is willing to buy these domestic assets. However, the Exchange Fund Ordinance does allow the Financial Secretary the flexibility to do so even though Hong Kong's monetary institution is a currency board. ${ }^{14}$ Suppose the Exchange Fund will indeed provide the foreign liquidity to avoid bank runs. If people decide to increase their foreign exchange holdings from 46.2 percent to 53 percent of M3, the accumulated earnings in the balance sheet of the Fund will disappear. If the foreign deposits ratio goes up further to 59.4 percent, all the fiscal reserve will also be used up.

These rather simplistic calculations tell us that a run on the Hong Kong dollar could occur even when the change in people's portfolio holdings is not exceptionally big. We do not have an estimate of the portfolio holdings as a function of other variables. However, one can reasonably speculate that the confidence in the HK dollar

13 Hong Kong Monetary Authority (1996).

14 The Exchange Fund Ordinance, Section 3 (2), states that "The Fund, or any part of it, may be held in Hong Kong currency or in foreign exchange or in gold or in silver or may be invested by the Financial Secretary in such securities or other assets as he, after having consulted the Exchange Fund Advisory Committee, considers appropriate." (Hong Kong Monetary Authority (1994), p. 51). See also footnote 3 . 
will suffer significantly and the link will face a crisis if the fiscal reserve is completely used up.

The amount of fiscal reserve is affected by shocks to the economy. Since the Hong Kong government has been following a reasonably stable fiscal policy, we focus our attention on supply shocks here. How big are the supply shocks if the fiscal reserve is to be eliminated? This can be answered by making use of the empirical estimates in this paper.

The long-run impulse response of the logarithm of $y(t)$ with respect to a supply shock of one standard deviation is 0.0143 . This means that a one-standard-deviation shock will reduce output permanently by 1.43 percent, other things being equal. Thus, we can calculate the post-shock output level $y(t) *$ by the formula

$$
y(t)^{*}=(1-0.0143 x) y(t)
$$

for a supply shock of $x$ standard deviations. Similarly for K periods of negative supply shocks, each of size $x$, the post-shock output level should be

$$
y(t)^{*}=(1-0.0143 x)^{K} y(t)
$$

In Table 8, we calculate the percentages, $100(y(t) * / y(t))$, for $x=1,2,3,4$ and $K=$ $1,2, \ldots . .8$. From data of $1985-1994$, the average ratios of total government expenditure and revenue to GDP are 16 percent and 16.8 percent, respectively. ${ }^{15}$ We assume that the revenue ratio is fixed. Post-shock revenue is

$$
0.168 y(t)^{*}=\left[0.168(1-0.0143 x)^{K}\right] y(t)
$$

Thus, the effect of the supply shock on revenue is equivalent to a "tax-cut" with the new, effective tax rate being the term inside the square brackets above. These are

\footnotetext{
15 Hong Kong Annual Report, various years.
} 
shown in Table 9. From GDP data, we can infer that each percentage point decline in the revenue-output ratio will reduce revenue by HK\$ 12 billion. Making use of Table 8 , one can come up with results in different scenarios. For example, if there are negative 3-standard-deviation supply shocks lasting for two years, then the loss in revenue every year will be approximately HK\$ 51.6 billion. It only takes about three years for the fiscal reserve to be completely depleted if political pressures prohibit the government from reducing its expenditures accordingly. Since major historical changes in Hong Kong's future are upcoming, large negative supply shocks or perhaps even significant structural shifts in the transition period cannot be ruled out. The stability of the currency board system in the future has yet to be tested.

Currency crises can lead to bank runs. But bank runs can occur because of other reasons too. Since the typical currency board does not provide a lender of last resort, bank runs are often regarded as the Achilles Heel of the system. Indeed banking crises did occur in Hong Kong a number of times, all during the currency board years. The government and the banking system resorted to several ways to deal with them.

In 1994 there were 180 licensed banks in Hong Kong, 16 of which were owned mostly by local shareholders (Hong Kong Monetary Authority, 1994, p. 90-91). Government policies towards runs on local and foreign banks seemed to be different. It did not attempt to support the Citibank in 1991 when rumors caused a short-lived run, nor did it try to rescue the Bank of Credit and Commerce International's Hong Kong branch before its collapse in the same year. However, it moved to take over two small local banks in the mid 1960s and three more in the period of 1982-86. It also provided some emergency funds to support five banks in the same period, four of which were later acquired by others. The note-issuing banks also played an important role in 
cushioning the shocks from the runs. They supported one bank in 1961, three in 1965 66 , and took over three more in the same period. Thus, in the 1960s, the government was relying mainly on the financially strong note-issuing banks to either lend to or take over the troubled local banks. In more recent years, the government seemed to have resorted to the Exchange Fund for playing the role of lender of last resort. ${ }^{16}$ This is another reason to say that some of the features of a currency board have been diluted in Hong Kong.

\section{What Can We Learn From Hong Kong's Experience?}

The performance of the currency board in Hong Kong has not been bad so far. Although it may have lowered output growth, inflation has also gone down. In fact, the more revealing results from the counter-factual exercises concern stability. When both regimes are subject to the same exogenous shocks, output and prices are less volatile under currency board.

The stability result is not general. Simulations on impulse responses show that output is less sensitive to supply shocks under currency board than under free-floating. On the other hand, demand shocks can cause stronger short-term volatility in output in a currency board system. The relative stability in output in Hong Kong to a large extent must have come from the government's self-discipline in fiscal policy, which is based on two rules: balanced budget or small surplus, and keeping government size

16 See Jao (1993, Chap. 13) and Ho et al (1991, Chap.1) for more details about banking crises in Hong Kong. 
small. Other countries without a stable rule-based fiscal policy may not do well to reduce output volatility even if they have currency boards. ${ }^{17}$

The fiscal restraint not only affects output stability, but also the credibility of the exchange rate system. A weakness of the currency board system is that people may doubt the determination and capability of the government to maintain perfect convertibility at the specified rate. The conservative fiscal policy has been instrumental in creating surpluses for almost every budgetary year. Without the significant fiscal reserve, confidence in the Hong Kong dollar may suffer. In recent years, since the Exchange Fund has been acting as if it could be the lender of last resort, its financial strength which is partly supported by a large fiscal reserve is all the more important. Perhaps a reason why fiscal policy in Hong Kong is coordinated with its monetary system is that the Financial Secretary has the authority to control both.

Despite the financial strength of the Exchange Fund, the Hong Kong dollar has occasionally been subject to considerable speculative pressure. For example, in midJanuary 1995, the Hong Kong dollar depreciated 0.4 percent briefly. In all such occasions, the speculations have been effectively countered (Hong Kong Monetary Authority (1995)). Given the excellent track records, do people have enough confidence in the Hong Kong dollar? As mentioned in Section 4.4, 46.2 percent of M3 is in deposits denominated in foreign currency. This large portion is an indication that

\footnotetext{
17 The Financial Secretary of Hong Kong last year articulated his commitment to the noninterventionist rule-based fiscal policy by referring to a story in Greek mythology. The half-bird half-lady Sirens sang so beautifully that all sailors who heard them would dive into the sea and try to swim to them, only to drown and die at their feet. He said that he would tie himself to the mast of the ship when he heard them singing. See Tsang (1995).
} 
people only have limited confidence in the future of the Hong Kong dollar, in spite of all the assurance that the government has provided.

Should other countries adopt the currency board system? The above analysis indicates that the decent performance in Hong Kong has been due to a combination of favorable factors, and yet, the possibility of monetary collapse cannot be ruled out. It is doubtful that too many countries have equal or better conditions. 


\section{References}

Bayoumi, T. and Eichengreen, B. 1993. Shocking aspects of European monetary integration. In Adjustment and growth in the European Monetary Union, ed. F. Torres and F. Giavazzi. Cambridge: Cambridge University Press.

1994. Macroeconomic adjustment under Bretton Woods and the postBretton-Woods float: An impulse response analysis. Economic Journal 104 (July): 813-27.

Bernanke, B. 1986. Alternative explanations of the money-income correlation. Carnegie - Rochester Conference Series on Public Policy 25: 49-99.

Blanchard, O. J. and Watson, M. 1986. Are business cycles all alike? In The American business cycle: Continuity and change, ed. R. Gordon. Chicago: University of Chicago Press.

Blanchard, O. J. and Quah, D. 1989. The dynamic effects of aggregate demand and supply disturbances. American Economic Review 79 (September): 655-673.

Doan, T. A. 1992. RATS user's manual version 4. Evanston, IL: Estima.

Eichengreen, B. 1994. International monetary arrangements for the 21 st century. Washington, D.C.: The Brookings Institution.

Giannini, C. 1992. Topics in structural VAR econometrics. Berlin: Springer-Verlag.

Greenwood, J. 1995. The debate on the optimum monetary system. Asian Monetary Monitor 19 (March-April): 1-5.

Hanke, S. H., Jonung, L. and Schuler, K. 1993. Russian currency and finance: A currency board approach to reform. London: Routledge.

Hanke, S. H. and Schuler, K. 1994. Currency boards for developing countries. San Francisco: Institute for Contemporary Studies Press.

Ho, R.Y.K., Scott, R.H. and Wong, K.A. 1991. The Hong Kong Financial System. Hong Kong: Oxford University Press.

Hong Kong Census and Statistics Department. 1995. Estimates of Gross Domestic Product 1961 to 1995 . Hong Kong: Government Printer.

Hong Kong Monthly Digest of Statistics, various issues. Hong Kong: Government Printer.

. Hong Kong Annual Digest of Statistics, various issues. Hong Kong:

Government Printer. 
Hong Kong Monetary Authority. 1994, 1995. Annual Report. Press and Publications Section, Hong Kong Monetary Authority.

1996. Monthly Statistical Bulletin, March issue. Press and Publications Section, Hong Kong Monetary Authority.

Jao, Y. C. 1991. Hong Kong's Financial System Towards the Future (in Chinese). Hong Kong: Joint Publishing (H.K.) Company, Ltd.

Johnson, N. L. and Kotz, S. 1970. Distributions in statistics -- continuous univariate distribution 1. New York: John Wiley \& Sons.

Kendall, M.G. and Stuart, A. 1958. The advanced theory of statistics, Vol. 1. London: C. Griffin \& Company.

Nugee, J. 1995. A brief history of the exchange fund. In Money and Banking in Hong Kong. Hong Kong: Hong Kong Monetary Authority.

Persson, T. and Tabellini, G. 1990. Macroeconomic policy, credibility and politics. Chur, Switzerland: Harwood Academic Publishers.

Sachs, J.D. and Larrain, F. 1993. Macroeconomics in the Global Economy. New York: Harvester Wheatsheaf.

Schwartz, A. J. 1993. Currency boards: Their past, present and possible future role. Carnegie-Rochester Conference Series on Public Policy 39: 147-187.

Sheng, A. 1995. The Linked Exchange Rate System: Review and Prospects. Hong Kong Monetary Authority Quarterly Bulletin (May): 54-61.

Sims, C. 1974. Seasonality in regression. Journal of the American Statistical Association 69: 618-626.

Sims, C. 1986. Are forecasting models usable for policy analysis? Federal Reserve Bank of Minneapolis Quarterly Review 10 (Winter): 2-16.

Tsang, D. 1995. Looking Downwards From the Olympics (in Chinese). Ming Pao (October).

Walters, A. A. and Hanke, S. 1992. Currency boards. In The new Palgrave dictionary of money and finance, ed. P. Newman, M. Milgate and J. Eatwell. London: Macmillan.

Watson, M. 1994. Vector autoregression and cointegration. In Handbook of Econometrics, Vol. 4, ed. R. F. Engle and D. L. McFadden. Amsterdam: Elsevier.

Williamson, J. 1995. What role for currency boards? Washington D.C.: Institute for International Economics. 
Table 1

The exchange rate regime for the Hong Kong dollar

\begin{tabular}{|c|c|c|}
\hline Date & Exchange rate regime & Reference rate \\
\hline Until 4 Nov 1935 & Silver standard & $=$ \\
\hline $6 \mathrm{Dec} 1935$ & \multirow[t]{2}{*}{ Pegged to Sterling } & $£ 1=\mathrm{HK} \$ 16$ \\
\hline 23 Nov 1967 & & $\mathrm{E} 1=\mathrm{HK} \$ 14.55$ \\
\hline 6 July 1972 & \multirow{2}{*}{$\begin{array}{l}\text { Fixed to US dollar with } \pm 2.25 \% \\
\text { intervention bands around a } \\
\text { central rate }\end{array}$} & $\mathrm{US} \$ 1=\mathrm{HK} \$ 5.65$ \\
\hline 14 Feb 1973 & & $\mathrm{US} \$ 1=\mathrm{HK} \$ 5.085$ \\
\hline 25 Nov 1974 & Free float & - \\
\hline 17 Oct 1983 & Pegged to US dollar & $\mathrm{US} \$ 1=\mathrm{HK} \$ 7.80$ \\
\hline
\end{tabular}

Source: Nugee (1995).

Table 2:

Summary statistics of VAR estimation

\begin{tabular}{|l|l|l|l|l|}
\hline & \multicolumn{2}{|c|}{ VAR 1 (free-floating) } & \multicolumn{2}{c|}{ VAR 2 (currency board) } \\
\hline dependent variable & output growth rate & inflation rate & output growth rate & inflation rate \\
\hline $\mathrm{R}^{2}$ & 0.35 & 0.53 & 0.35 & 0.43 \\
$\mathrm{DW}$ & 1.7 & 1.58 & 2.01 & 1.97 \\
Ljung-Box Q & {$[0.42]$} & {$[0.88]$} & {$[0.86]$} & {$[0.12]$} \\
\hline overall significance & {$[0.01]$} & {$[0.001]$} & $83 \mathrm{Q}-95 \mathrm{Q} 3$ \\
\hline data range & $75 \mathrm{Q} 1-83 \mathrm{Q} 3$ & 83 & \\
\hline
\end{tabular}

- Numbers in squared brackets are p-values.

- "Overall significance" reports the p-value of a likelihood ratio test for the null hypothesis that all regressors in the system (except the constant terms) are zero.

Table 3

Characteristics of structural disturbances

\begin{tabular}{|c|c|c|c|c|}
\hline & \multicolumn{2}{|c|}{ Demand shocks } & \multicolumn{2}{|c|}{ Supply shocks } \\
\hline & Free-floating & Currency Board & Free-floating & Currency Board \\
\hline Skewness & $-1.01[0.003]$ & $-0.18[0.57]$ & $-0.91[0.008]$ & $-0.31[0.34]$ \\
\hline Kurtosis & $4.50 \quad[0.03]$ & $3.47[0.38]$ & $4.69[0.01]$ & $2.91 \quad[0.95]$ \\
\hline Maximum & 1.84 & 2.40 & 1.97 & 2.04 \\
\hline Minimum & -3.17 & -2.69 & -3.06 & -2.64 \\
\hline
\end{tabular}

- Skewness $\left(b_{1}{ }^{1 / 2}\right)=m_{3} / m_{2}^{3 / 2}$ and Kurtosis $\left(b_{2}\right)=m_{4} / m_{2}{ }^{2} \cdot m_{k}$ is the $k$ th sample moment around mean.

- Numbers in squared brackets are $\mathrm{p}$-values for testing either the population skewness $=0$ (symmetry) or kurtosis $=3$ (normal shape).

- For testing symmetry, Fisher's test statistic $\xi=x\left(1+3 / n+91 / 4 n^{2}\right)-(3 / 2 n)(1-111 / 2 n)\left(x^{3}-3 x\right)$ $\left(33 / 8 n^{2}\right)\left(x^{5}-10 x^{3}+15 x\right)$ is approximately distributed as $N(0,1)$ under the null hypothesis, where $x$ $=b_{1}{ }^{1 / 2}(n-1) /(6(n-2))^{1 / 2}$, and $n$ is the sample size. The approximate normality is very accurate even in small sample, see Kendall and Stuart (1958) p. 298.

- For testing kurtosis $=3$, the test statistic $z=y[(n-1)(n-2)(n-3) / 24 n(n+1)]^{1 / 2}$ is approximately distributed as $N(0,1)$ under the null hypothesis, where $y=\left[n^{2} /(n-1)(n-2)(n-3)\right]\left[(n+1) m_{-}-3(n-\right.$ $\left.1) m_{2}{ }^{2}\right] / s^{4}$, and $s$ is the sample standard deviation (with divisor $n-1$ ). See Kendall and Stuart (1958) p.305-306. 
Table 4

Percentage of forecast error variance explained by demand shocks

\begin{tabular}{|l|l|l|l|l|}
\hline & \multicolumn{2}{|c|}{ Output growth rate } & \multicolumn{2}{c|}{ Inflation rate } \\
\hline Quarter & Free-floating & Currency Board & Free-floating & Currency Board \\
\hline 1 & 0.66 & 67.16 & 96.57 & 16.71 \\
4 & 9.62 & 57.71 & 86.40 & 37.79 \\
8 & 9.25 & 62.61 & 82.38 & 37.52 \\
12 & 9.63 & 62.65 & 82.05 & 38.78 \\
16 & 9.76 & 62.70 & 81.83 & 39.10 \\
20 & 9.75 & 62.78 & 81.83 & 39.21 \\
24 & 9.76 & 62.80 & 81.79 & 39.27 \\
28 & 9.77 & 62.81 & 81.79 & 39.28 \\
32 & 9.77 & 62.81 & 81.79 & 39.29 \\
\hline
\end{tabular}

- The corresponding percentages explained by supply shocks are given by 100 minus the table entries

Table 5 Percentage of forecast error variance explained by demand shocks

\begin{tabular}{|l|l|l|l|l|}
\hline & \multicolumn{2}{|c|}{ Output level } & \multicolumn{2}{c|}{ Price level } \\
\hline Quarter & Free-floating & Currency Board & Free-floating & Currency Board \\
\hline 1 & 0.002 & 80.44 & 99.94 & 8.28 \\
4 & 0.124 & 73.51 & 99.99 & 74.38 \\
8 & 0.050 & 33.06 & 99.87 & 86.20 \\
12 & 0.024 & 16.18 & 99.45 & 84.55 \\
16 & 0.013 & 9.21 & 99.20 & 83.16 \\
20 & 0.008 & 5.65 & 99.12 & 83.45 \\
24 & 0.005 & 3.79 & 99.00 & 83.37 \\
28 & 0.004 & 2.72 & 98.88 & 83.09 \\
32 & 0.003 & 2.03 & 98.80 & 83.02 \\
\hline
\end{tabular}

- The corresponding percentages explained by supply shocks are given by 100 minus the table entries

Table 6

Counter-factual simulation

\begin{tabular}{|l|l|l|l|l|}
\hline & \multicolumn{2}{|c|}{ Output growth rate \% } & \multicolumn{2}{c|}{ Inflation rate \% } \\
\cline { 3 - 5 } & Mean & Standard dev. & Mean & Standard dev. \\
\hline Case 1 (1975-83) & & & & \\
Actual (FF) & 1.54 & 2.94 & 2.07 & 1.55 \\
Simulated (CB) & 1.27 & 2.46 & 1.82 & 1.21 \\
\hline Case2 (1983-95) & & & & \\
Actual (CB) & 1.22 & 2.23 & 1.94 & 1.05 \\
Simulated (FF) & 1.51 & 2.79 & 2.13 & 1.36 \\
\hline
\end{tabular}

- $\mathrm{CB}=$ currency board

- $\mathrm{FF}=$ free floating 
Table 7 Exchange Fund Balance Sheet

\begin{tabular}{|c|c|c|c|c|c|c|c|c|}
\hline \multicolumn{9}{|l|}{ HKSmn } \\
\hline & 1988 & 1989 & 1990 & 1991 & 1992 & 1993 & 1994 & $6 / 1995$ \\
\hline \multicolumn{9}{|l|}{ ASSETS } \\
\hline Foreign currency assets & 127,089 & 149,152 & 192,323 & 225,333 & 274,948 & 335.499 & 384,359 & 418,334 \\
\hline \multirow{2}{*}{ Hong Kong dollar as sets } & 5,962 & 9,625 & 3,874 & 10,788 & 12.546 & 12,987 & 24,126 & 31,454 \\
\hline & 133,051 & 158,777 & 196,197 & 236,121 & 287,494 & 348,486 & 408,485 & 449,788 \\
\hline \multicolumn{9}{|l|}{ LIA B LITIES } \\
\hline Certificate of Indebtedness & 31,731 & 37,191 & 40,791 & 46.410 & 58.130 & 68,801 & 74.301 & 74,630 \\
\hline Fiscal Reserve Account & 38,269 & 52,546 & 63,226 & 69,802 & 96.145 & 115,683 & 131,240 & {$[43,908$} \\
\hline Coins in circulation & 1,890 & 2,012 & 2,003 & 2,299 & 2,559 & 2,604 & 3,372 & 3,332 \\
\hline Exchange Fund Bills and Notes & 0 & 0 & 6,671 & 13,624 & 19,324 & 25,157 & 46,140 & 50,840 \\
\hline Balance of banking system & 860 & 978 & 480 & 500 & 1,480 & 1,385 & 2,208 & 2,247 \\
\hline \multirow{2}{*}{ Other liabilities } & 2.554 & 1,603 & 391 & 4,834 & 3,220 & 7,314 & 22,614 & 22,056 \\
\hline & 75,304 & 94,330 & 113,562 & 137,469 & 180,858 & 220,944 & 279,875 & 297,013 \\
\hline ACCUMULATED EARNINGS & 57,747 & 64,447 & 82,635 & 98,652 & 106,636 & 127,542 & 128.610 & 152,775 \\
\hline
\end{tabular}

Source: Hong Kong Monetary Authority (1994, 1996).

Table 8 Post-shock output level (\% of pre-shock output)

\begin{tabular}{|c|c|c|c|c|}
\hline & \multicolumn{4}{|c|}{$\begin{array}{c}\text { size of negative supply shocks } \\
\text { (in standard deviation) }\end{array}$} \\
\hline Duration (quarters) & 1 & 2 & 3 & 4 \\
\hline 1 & 98.6 & 97.1 & 95.7 & 94.3 \\
2 & 97.2 & 94.4 & 91.6 & 88.9 \\
3 & 95.8 & 91.7 & 87.7 & 83.8 \\
4 & 94.4 & 89.0 & 83.9 & 79.0 \\
5 & 93.1 & 86.5 & 80.3 & 74.5 \\
6 & 91.7 & 84.0 & 76.9 & 70.2 \\
7 & 90.4 & 81.6 & 73.6 & 66.2 \\
8 & 89.1 & 79.3 & 70.4 & 62.4 \\
\hline
\end{tabular}

Table 9 Post-shock effective revenue-output ratio \%

\begin{tabular}{|c|c|c|c|c|}
\hline & \multicolumn{4}{|c|}{$\begin{array}{c}\text { size of negative supply shocks } \\
\text { (in standard deviation) }\end{array}$} \\
\hline Duration (quarters) & 1 & 2 & 3 & 4 \\
\hline 1 & 16.6 & 16.3 & 16.1 & 15.8 \\
2 & 16.3 & 15.9 & 15.4 & 14.9 \\
3 & 16.1 & 15.4 & 14.7 & 14.1 \\
4 & 15.9 & 15.0 & 14.1 & 13.3 \\
5 & 15.6 & 14.5 & 13.5 & 12.5 \\
6 & 15.4 & 14.1 & 12.9 & 11.8 \\
7 & 15.2 & 13.7 & 12.4 & 11.1 \\
8 & 15.0 & 13.3 & 11.8 & 10.5 \\
\hline
\end{tabular}




\section{Per capita real GDP growth rate \%}

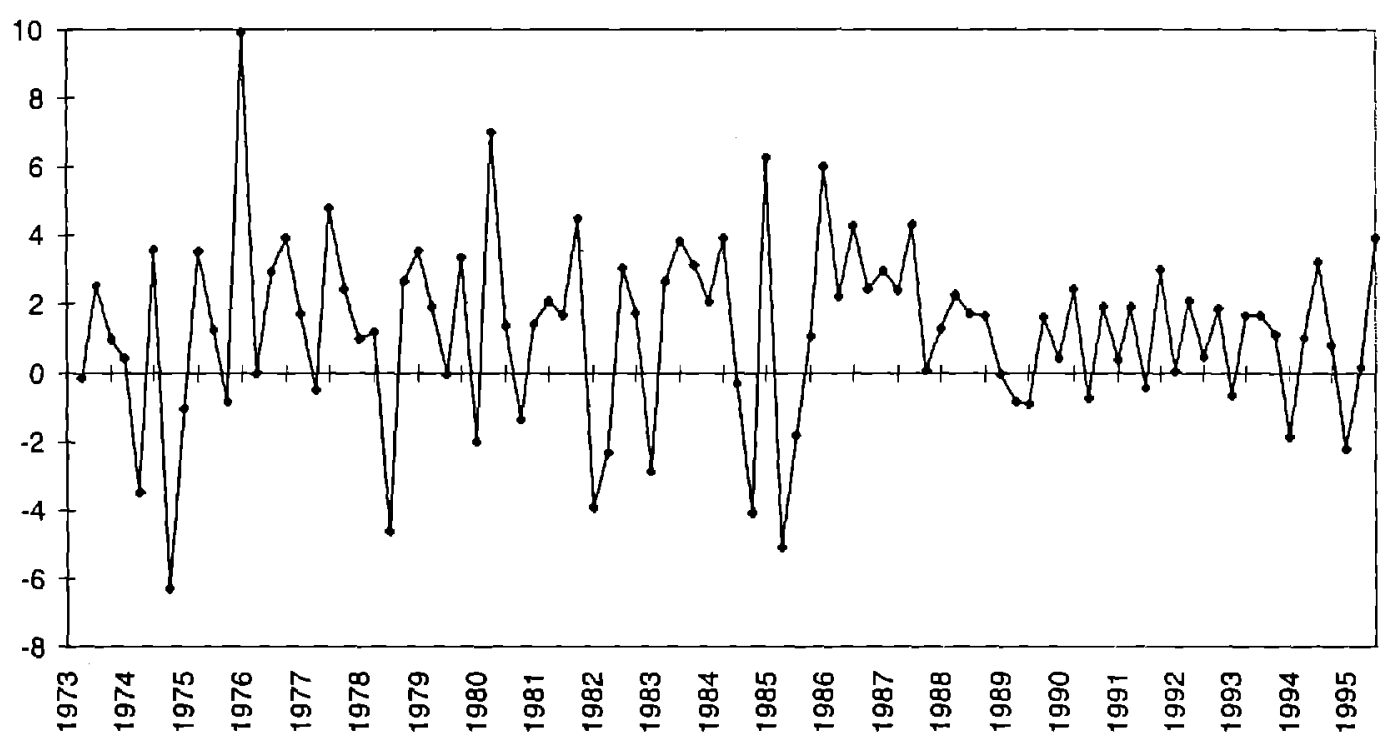

Figure 1a

Inflation rate \%

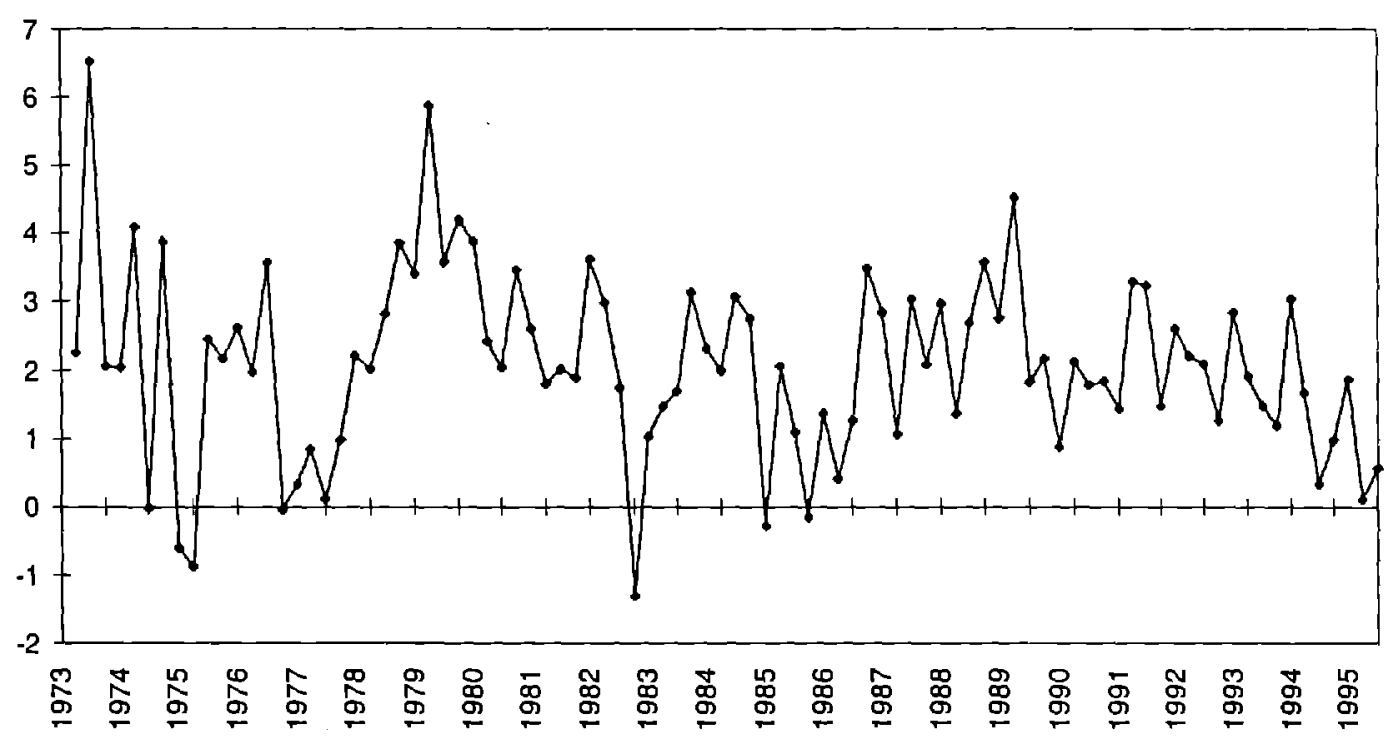

Figure 1b 


\section{Demand Shocks}

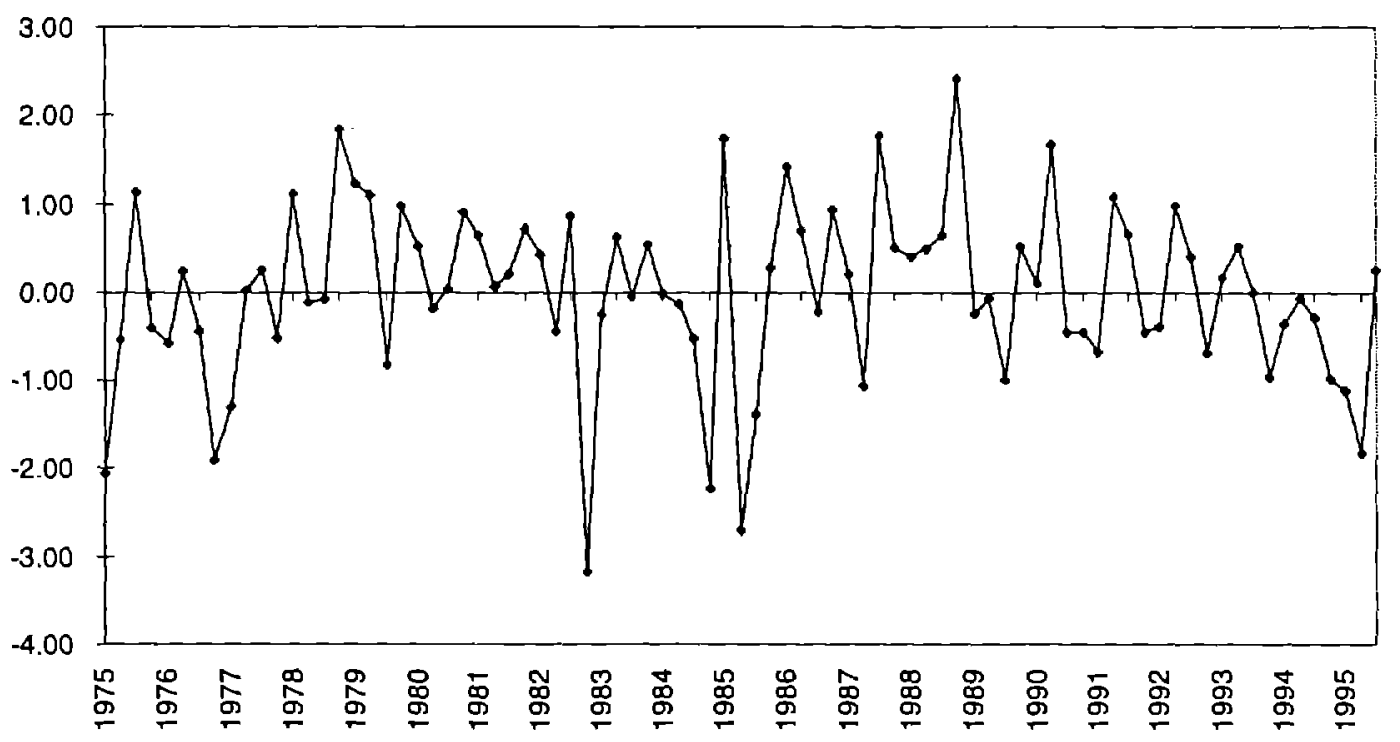

Figure 2a

\section{Supply Shocks}

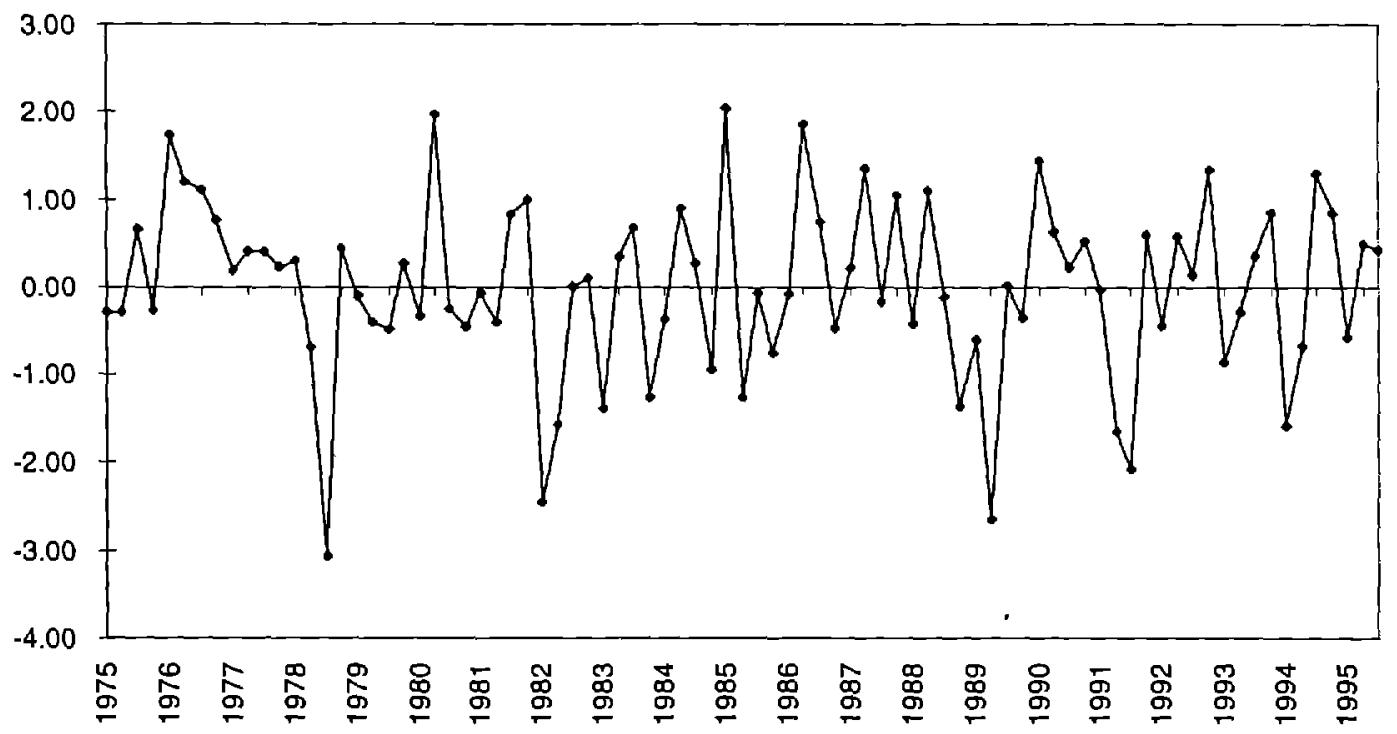

Figure 2b 
Density function of demand shocks

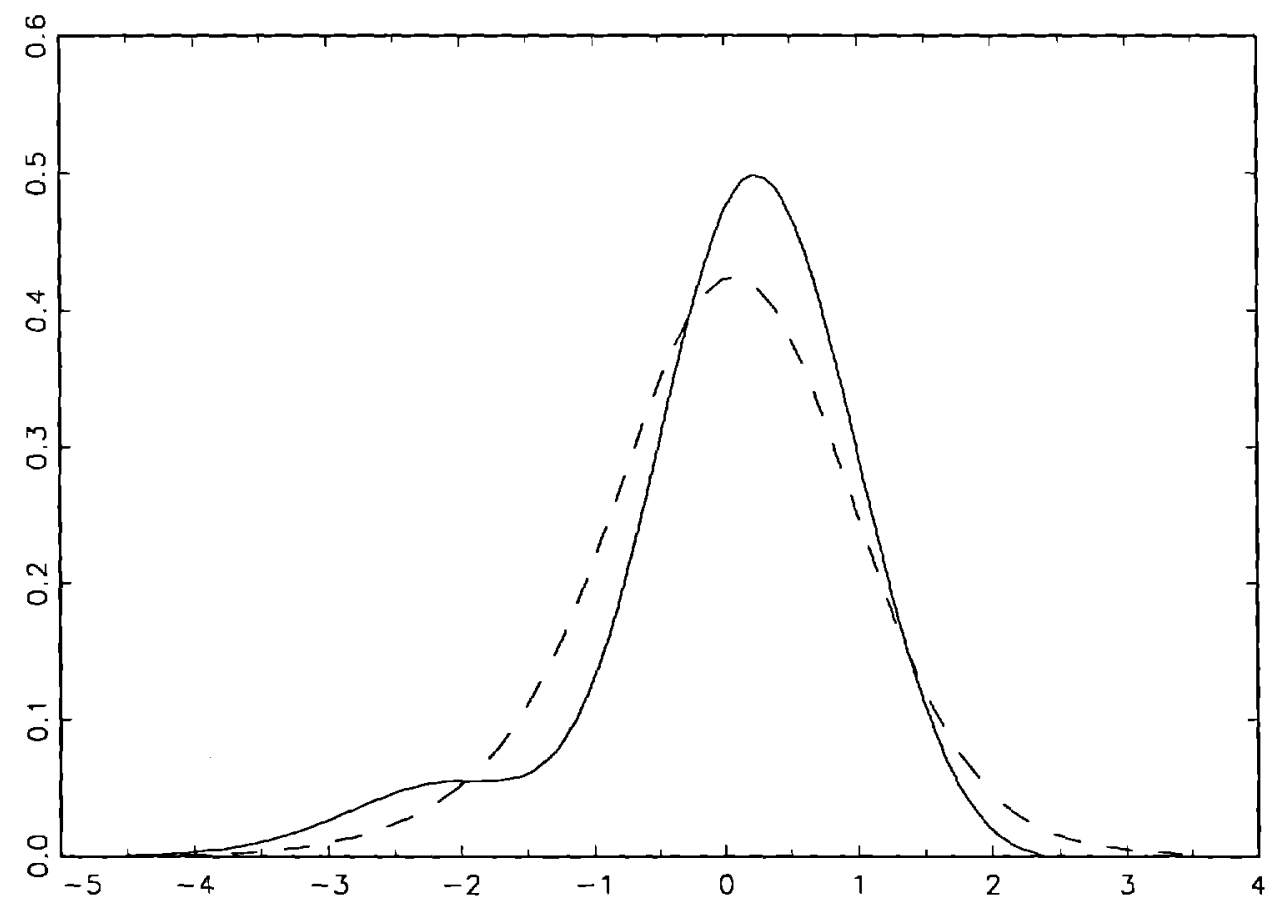

Figure 3a

Density function of supply shocks

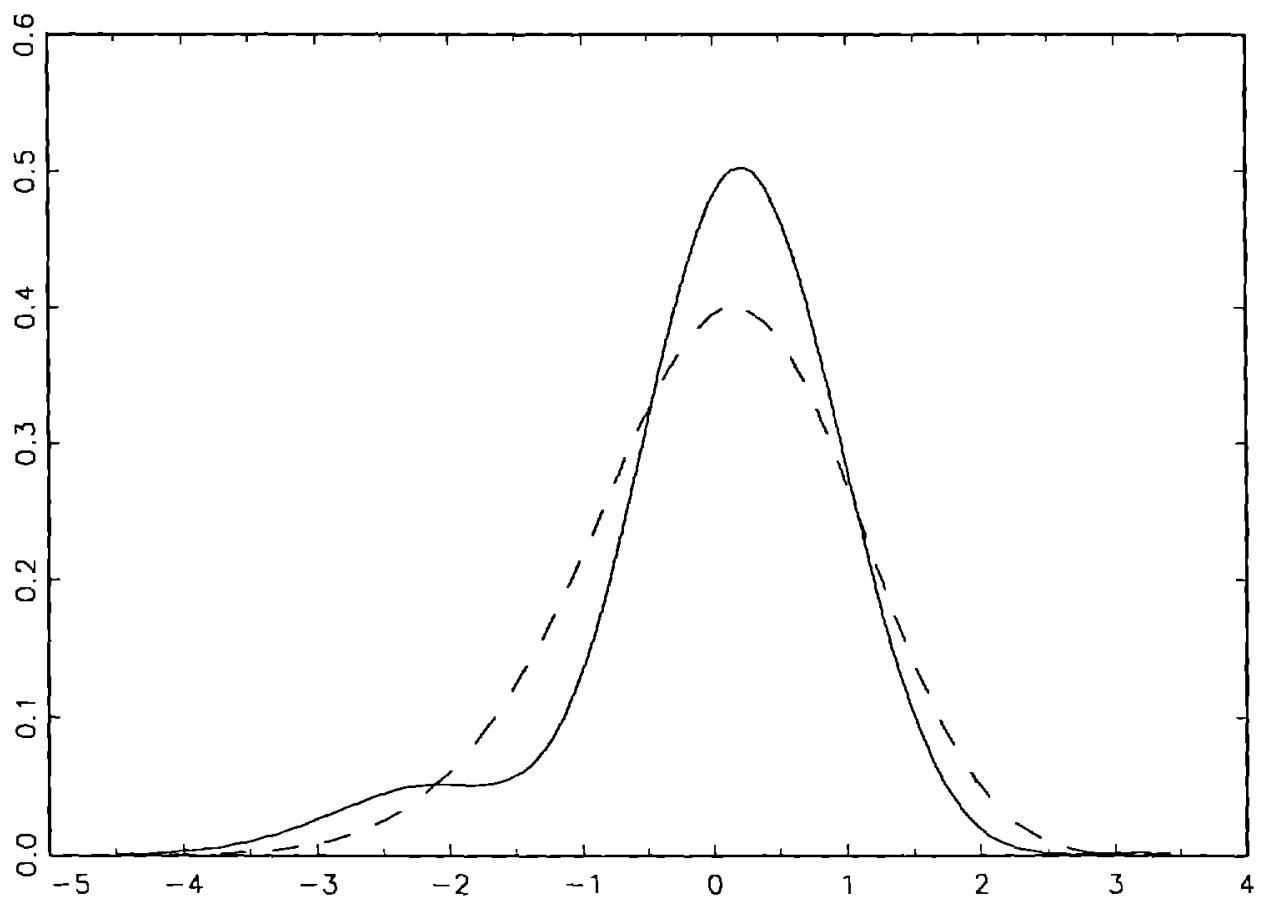

Figure 3b

Solid line $=$ free-floating period; Dashed line = currency board period 


\section{Output Response to Demand Shocks}

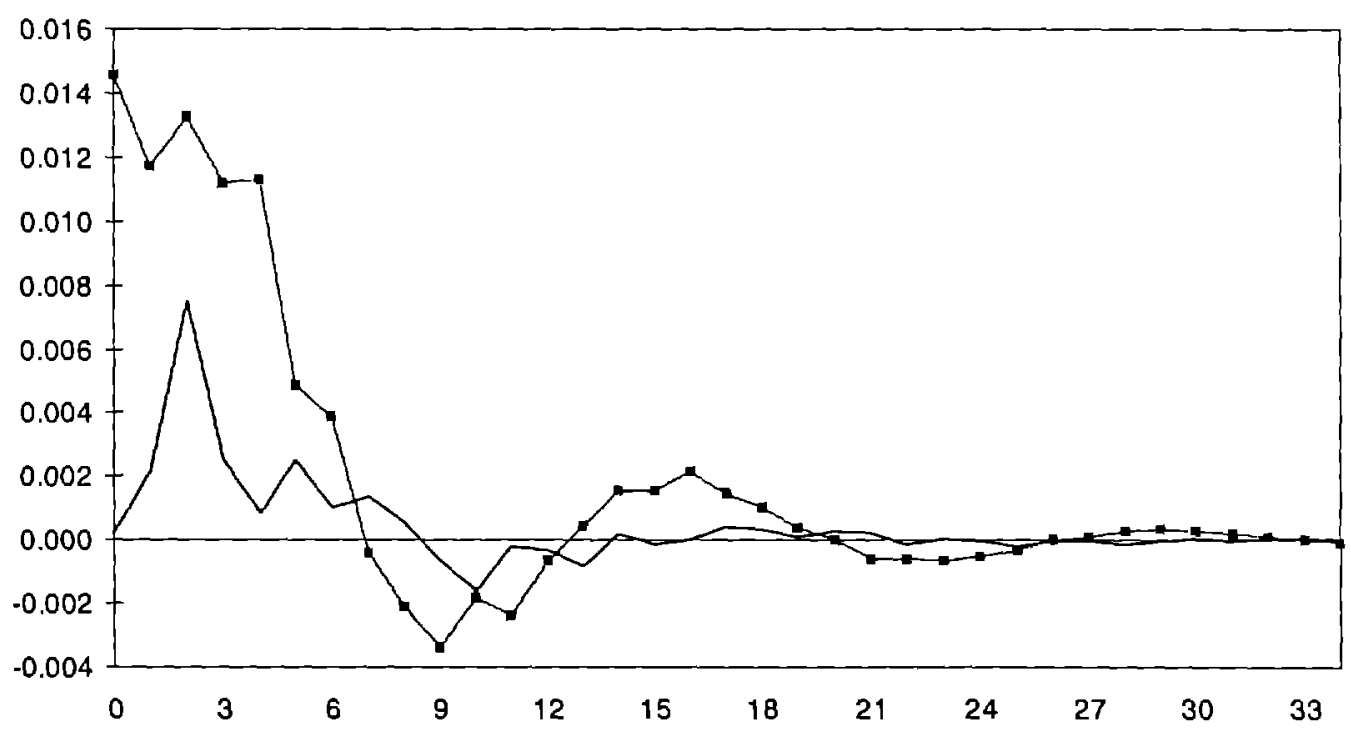

Figure 4a

Price Response to Demand Shocks

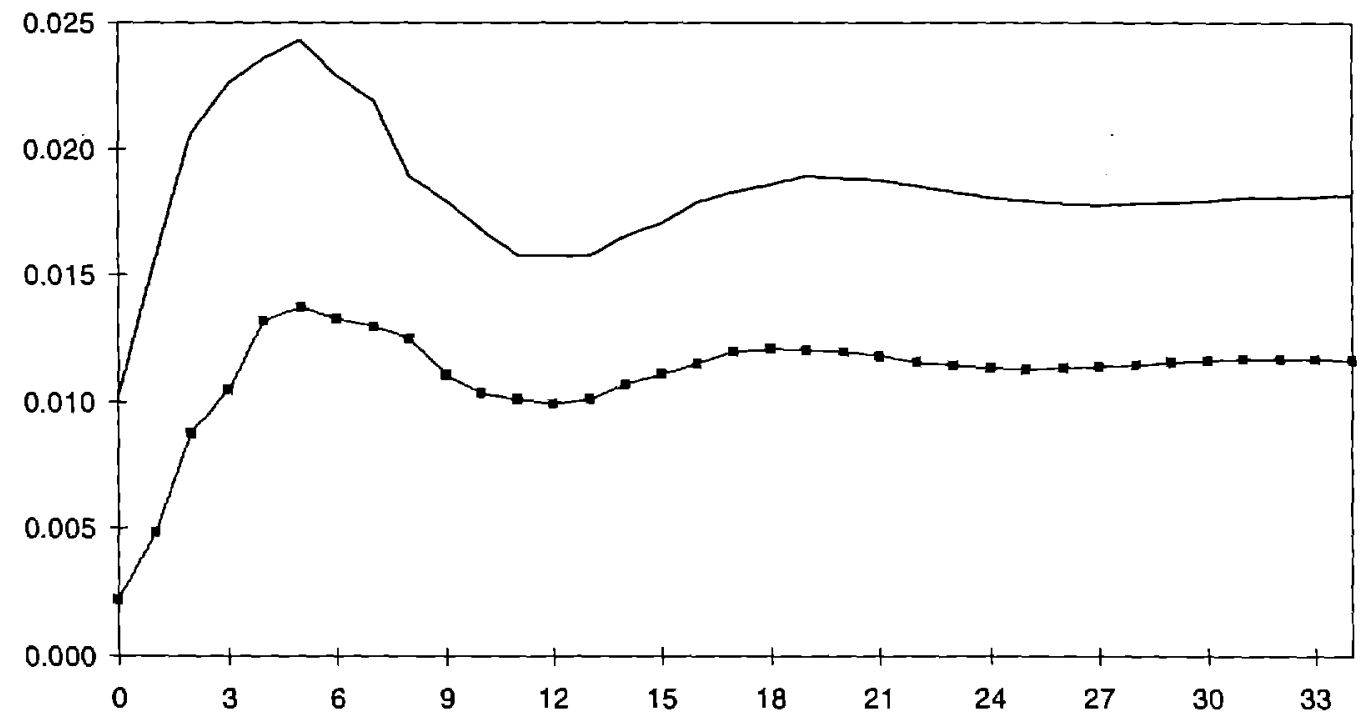

Figure 4b

Plain line = free-floating period; Boxed line $=$ currency board period 


\section{Output Response to Supply Shocks}

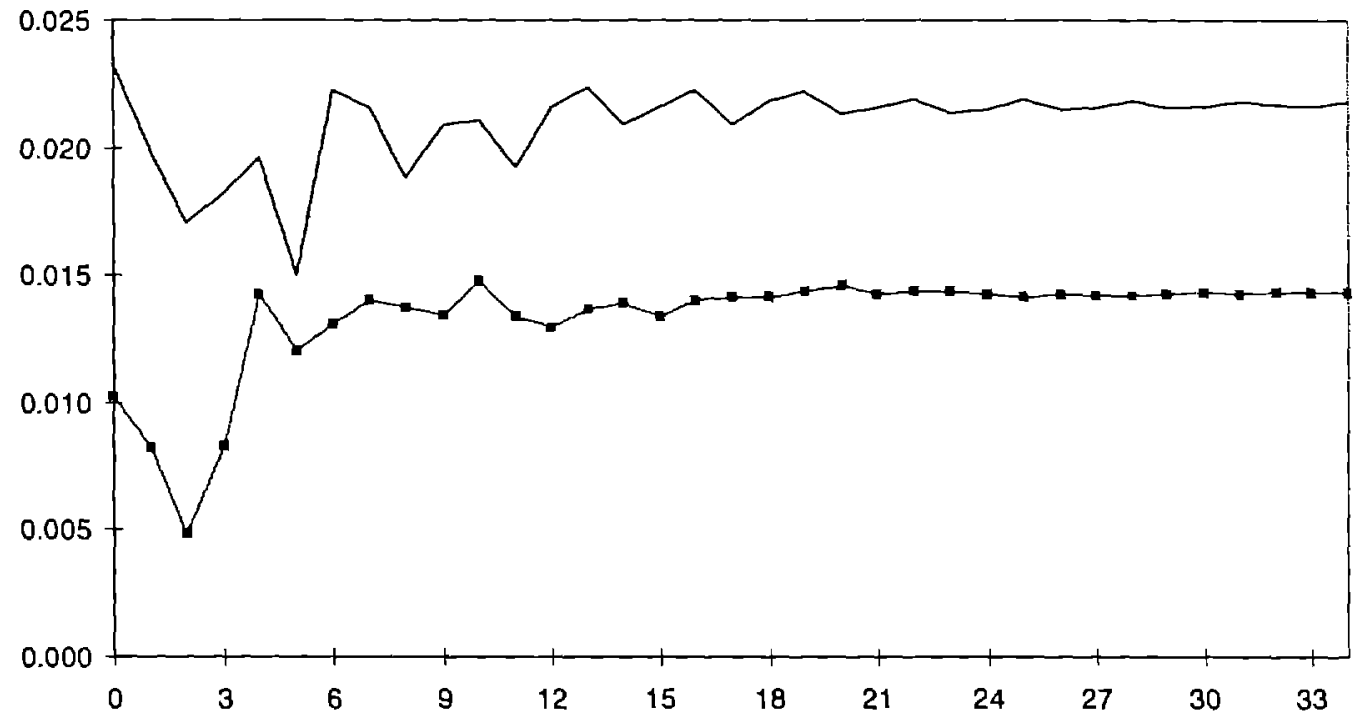

Figure 5a

Price Response to Supply Shocks

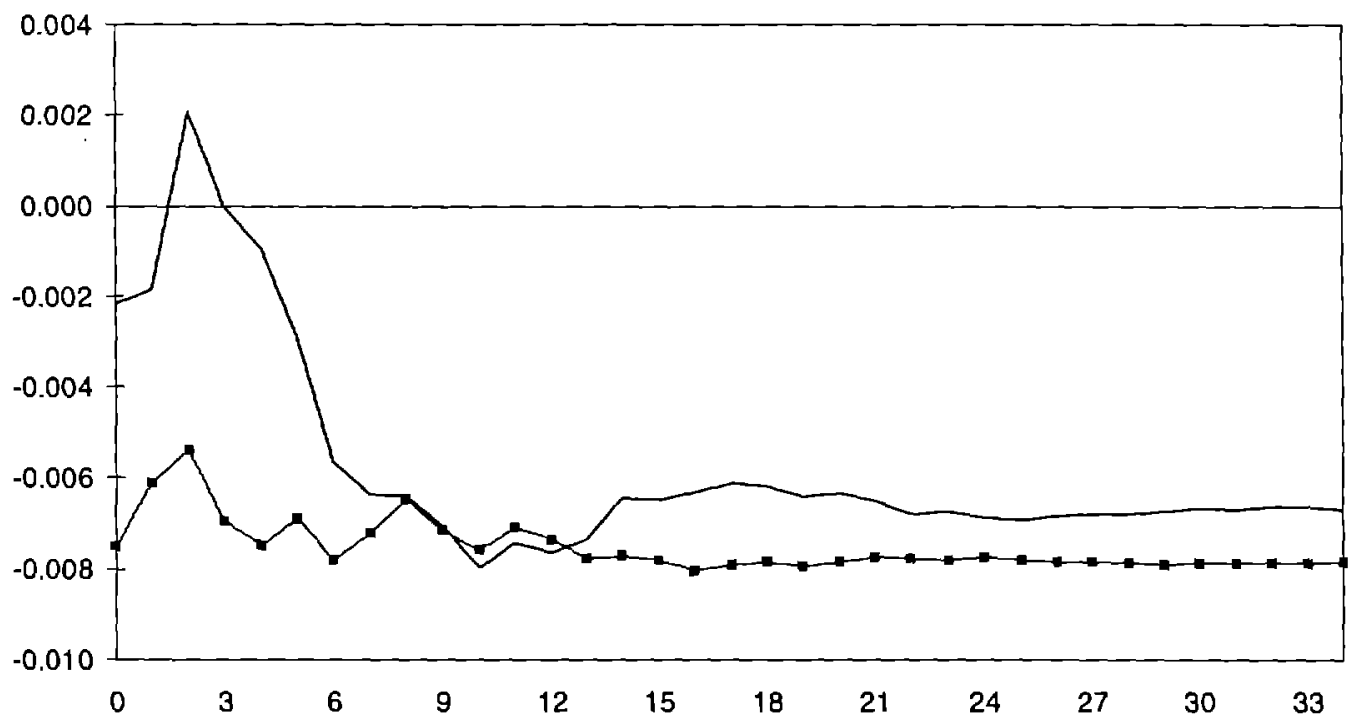

Figure 5b

Plain line = free-floating period; Boxed line $=$ currency board period 


\section{Output Level (in log): Case 1}

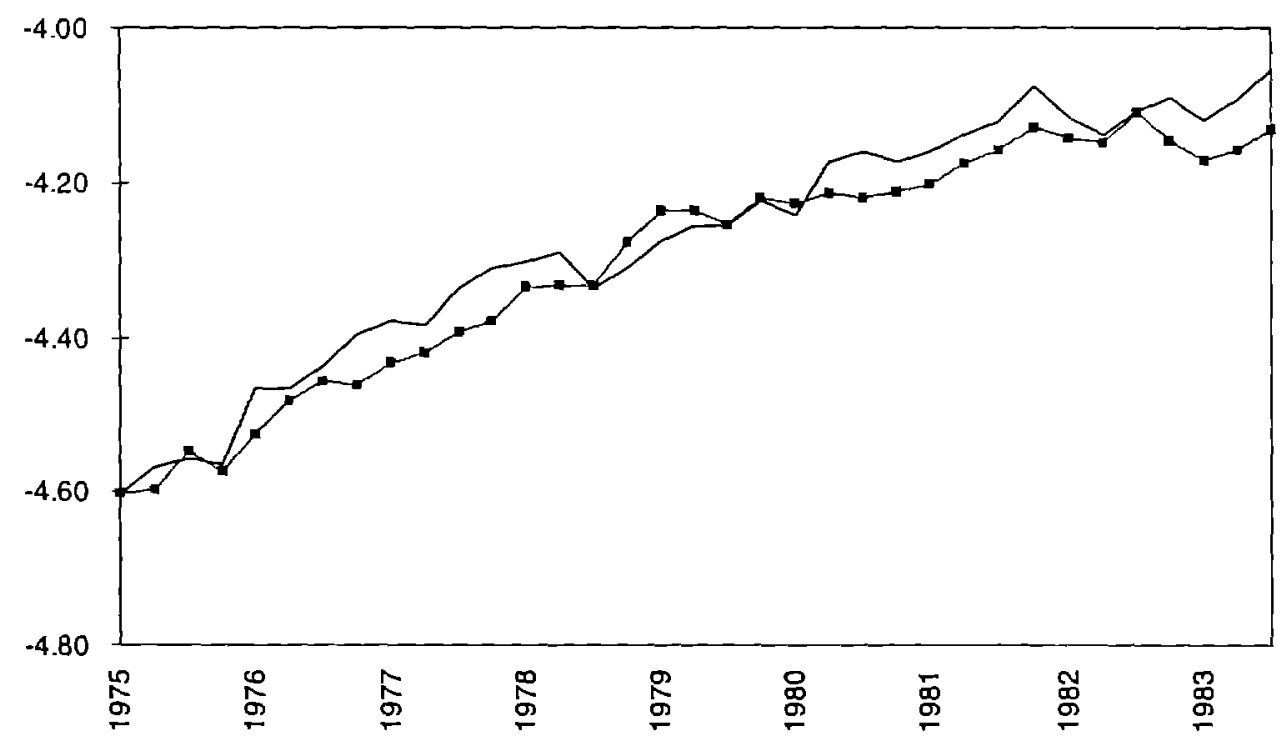

Figure 6a

Price Level (in log): Case 1

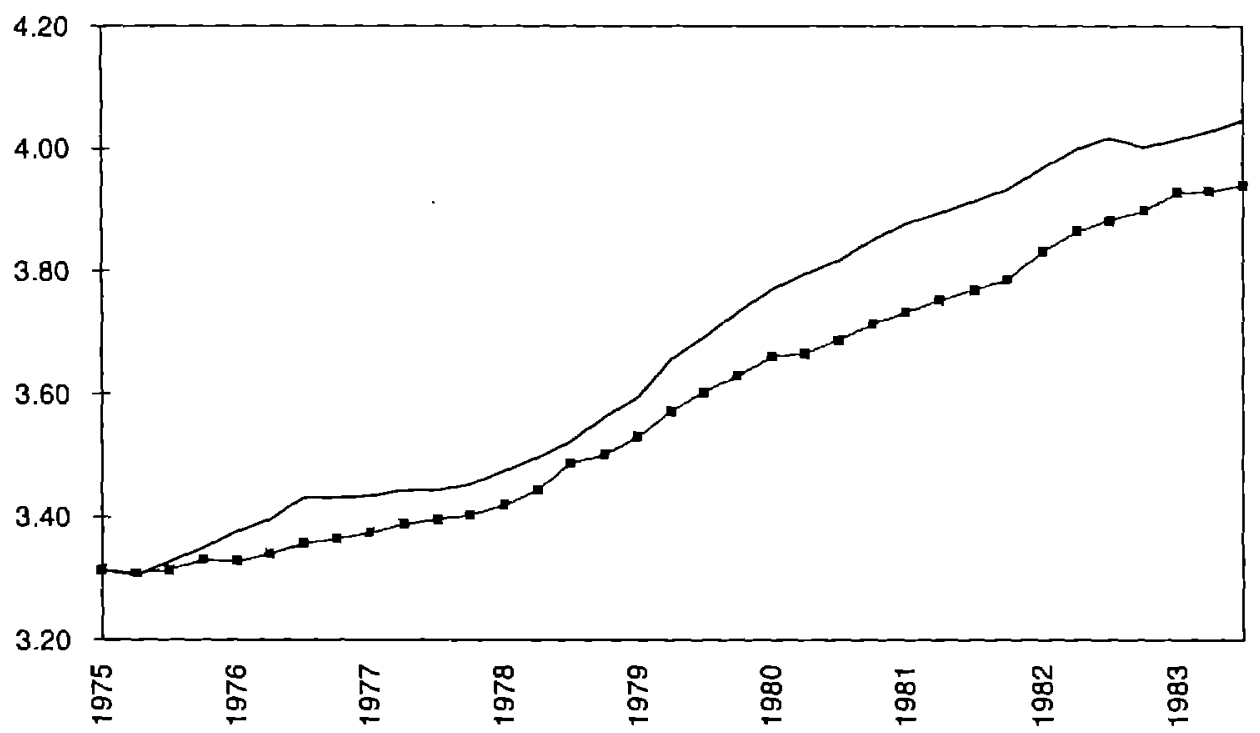

Figure 6b

Plain line = actual (free-floating); Boxed line = simulated (currency board) 
Output Level (in log): Case 2

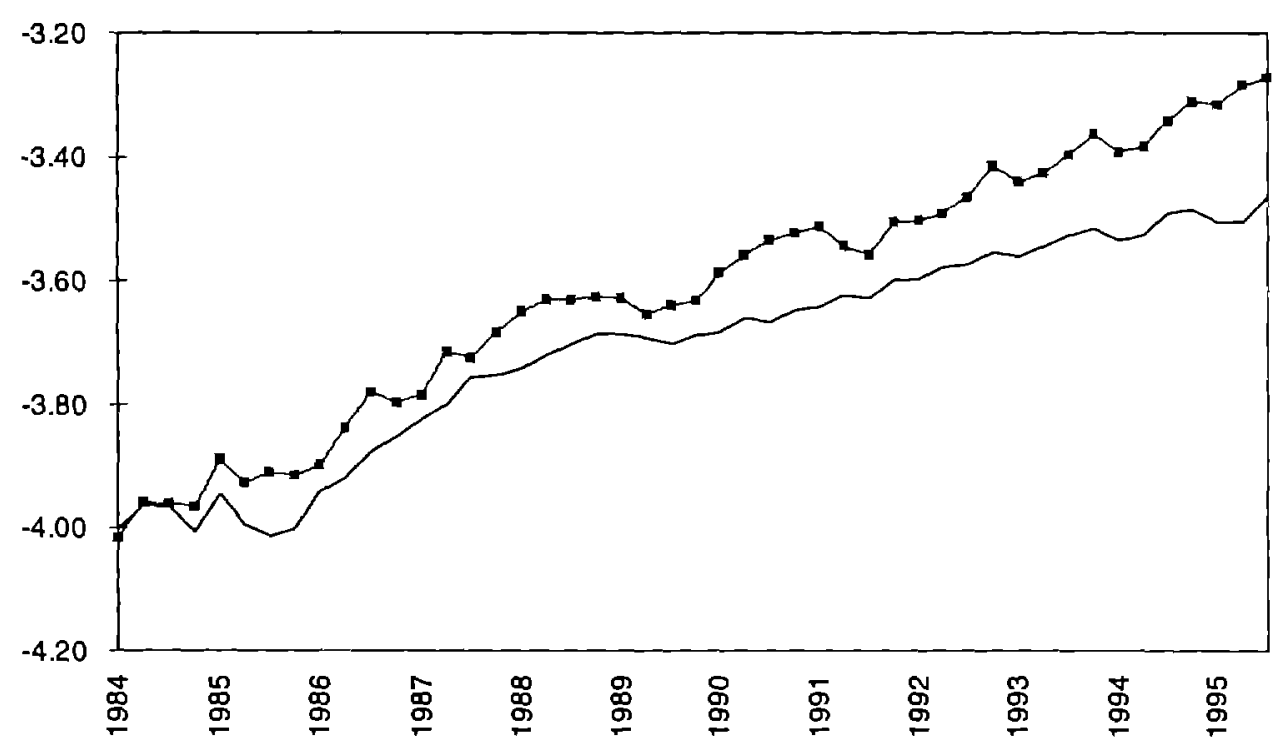

Figure 7a

Price Level (in log): Case 2

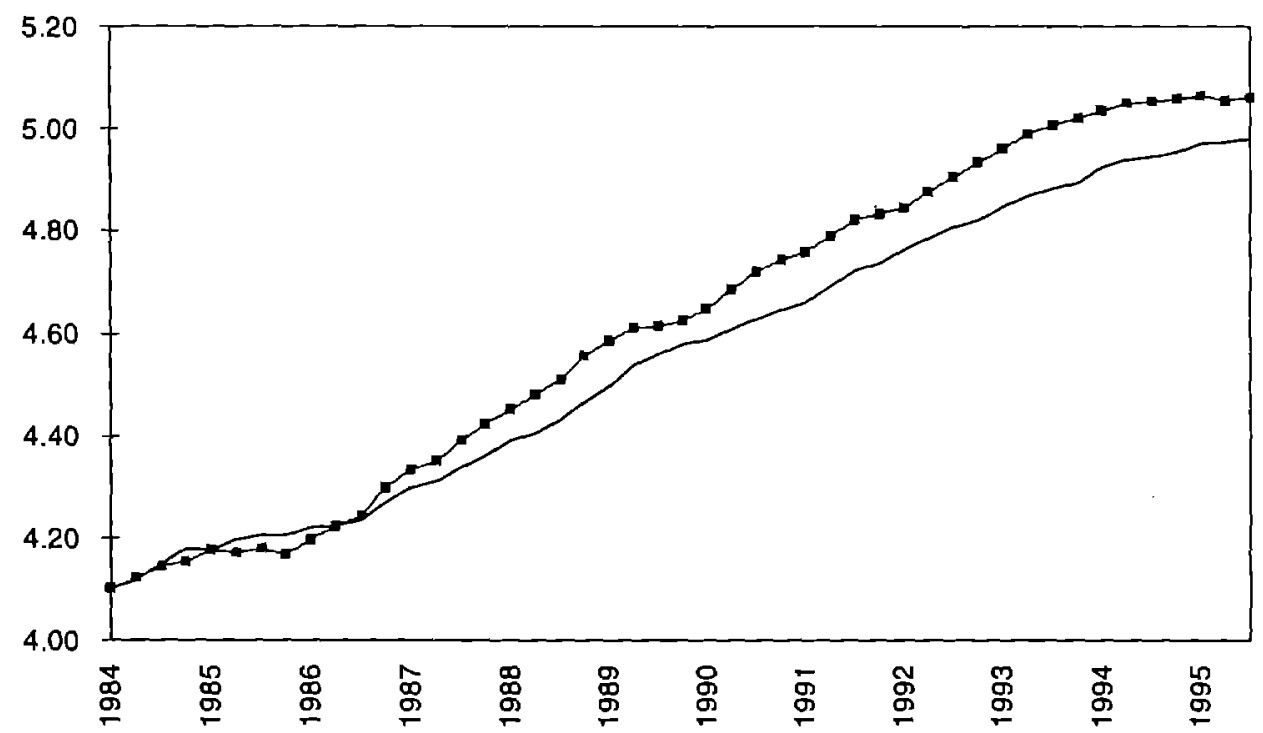

Figure $7 b$

Plain line = actual $($ currency board); Boxed line = simulated (free-floating) 